\title{
Mentorship during undergraduate surgical training: comparing perceptions of medical students and faculty at two institutions in South Africa and Sweden
}

\author{
AJ Scott, ${ }^{1}$ (i) G Drevin, ${ }^{2}$ iD L Pavlović, ${ }^{3}$ M Nilsson, ${ }^{4}$ (iD JEJ Krige, ${ }^{5}$ (D) E Jonas ${ }^{5}$ (iD \\ ${ }^{1}$ Paarl Hospital, South Africa \\ ${ }^{2}$ Gotland Region, Sweden \\ ${ }^{3}$ Department of Medicine, Karolinska Institutet, Sweden \\ ${ }^{4}$ Division of Surgery, Department of Clinical Science, Intervention and Technology, Karolinska Institutet, Sweden \\ ${ }^{5}$ Surgical Gastroenterology Unit, Division of General Surgery, University of Cape Town, South Africa
}

Corresponding author, email: alex.scott@alumni.uct.ac.za

Background: Having a mentor during undergraduate surgical training has been shown to positively influence medical students by increasing interest in surgery, improving confidence, and assisting in career planning. This study aimed to evaluate and compare medical student and faculty perceptions of mentorship during undergraduate surgical training and compare results between two teaching institutions in South Africa and Sweden.

Methods: An electronic, online questionnaire was anonymously distributed to medical students and general surgical faculty at the University of Cape Town (UCT), South Africa, and Karolinska Institutet (KI), Stockholm, Sweden. The questionnaire consisted of multiple choice, true or false, and five-point Likert scale questions, exploring perceptions of mentorship and role models, as well as rating the most important mentor characteristics.

Results: Approximately one third $(34.2 \%)$ of students stated they had a mentor during their surgical training, with significant differences found between student cohorts $(p<0.001)$. The 'registrar' was most commonly reported as the best role model for medical students by faculty from both UCT $(50.0 \%)$ and KI $(69.4 \%)$, as well as UCT students $(36.6 \%)$. Students rated the following mentor qualities significantly higher compared to faculty: student encouragement $(p=0.037)$, adequate supervision $(p=0.007)$, setting of fair expectations $(p=0.002)$, and teaching skills $(p=0.010)$.

Conclusion: With significant differences existing in the perceptions of medical students and faculty regarding mentorship and role models during undergraduate surgical training in both South African and Swedish institutions, reconciling and harmonising these differences will be crucial in fostering constructive mentoring relationships.

Keywords: mentorship, role model, perception, surgical education

\section{Introduction}

Many factors play a role in stimulating interest in surgery amongst medical students with past literature indicating a positive influence from surgical mentors and role models. ${ }^{1} \mathrm{~A}$ mentor has been described as a person who plays an active role in guiding and communicating with junior colleagues, whereas a role model may not have a defined and overt role in the guidance of a learner, yet his or her actions and attitudes may be consciously or unconsciously emulated. ${ }^{2}$ Mentorship within surgical disciplines is a key component to the success of young surgeons, providing additional means, complementary to formal training, to shape their surgical careers. ${ }^{3}$ Additionally, the presence of role models and mentors has been shown to influence medical students in their future career choice and choice of specialty, and promotes interest in surgical disciplines. ${ }^{4}$ However, the involvement of surgical faculty in mentorship programmes is curtailed because of clinical and research obligations. ${ }^{5,6}$ Furthermore, despite the recognised importance of mentoring in medical curricula, many institutions do not offer any form of formal mentorship programme to medical students. ${ }^{7}$

Literature comparing perceptions of mentorship and role-modelling between students and faculty is scarce. Two cross-sectional studies, ${ }^{6,8}$ where electronic surveys were administered to medical students and surgical faculty during a plastic surgery rotation, explored mentee-mentor relationships. Seventy-seven per cent $(77 \%)$ of medical students in these studies reported having had a mentor during their surgical training, whereas $83.5 \%$ of faculty reported having had a mentee. Additionally, faculty were reported to prefer meeting less frequently and in less personalised formats compared to mentees. Mentors reported time constraints and a lack of exposure to medical students as barriers to suitable mentorship. Importantly, mentees reported a lack of female mentors as a barrier to mentorship, underpinning the central role of gender in mentoring relationships. It has been suggested that the lack of female mentors and role models that female students can identify 
with may result in decreased interest in surgery as a career option. ${ }^{2,9}$

A qualitative study from Uganda explored student and faculty experiences and perceptions of the mentorship programme in the Health Sciences Faculty of Makerere University. ${ }^{10}$ Encouragingly, focus group discussions and key informant interviews in this study reported that both mentees and mentors had similar definitions and desired characteristics for a mentor and a mentoring relationship. Both groups also stated that the relationship was more likely to be successful if the mentors were freely chosen compared to being assigned. The article also highlighted barriers to mentorship, which included a lack of formalised structural programmes, a lack of clarity regarding roles and expectations, as well as time constraints. ${ }^{10}$

In a prior publication, ${ }^{11}$ we explored medical student and faculty perceptions of the current undergraduate surgical curriculum, as well as existing teaching methods, between a South African and Swedish institution. We now aim to continue the analysis of this cohort by evaluating perceptions of mentorship and role models during undergraduate surgical training. Understanding the mentoring views of both students and faculty may strengthen efforts to establish efficient mentoring programmes, potentially attracting more prospective trainees to pursue a surgical career.

\section{Materials and methods}

As this study is based on the same study cohort which was used for assessing medical student and faculty perceptions of the undergraduate surgical curriculum and teaching methods in the first, already published paper, there are similarities in the description of the background of both institutions, study population, and study procedure. ${ }^{11}$

\section{Background}

The University of Cape Town (UCT) Faculty of Health Sciences is the oldest medical school in sub-Saharan Africa. The UCT Bachelor of Medicine and Surgery (MBChB) programme accepts approximately 220 medical students each year. The degree comprises six years of full-time academic and clinical study. Years one to three form the foundation in which the basic sciences are taught in both traditional lecture-based, as well as project-based learning. Years four to six consist predominantly of clinical teaching in the various medical and surgical disciplines. During the fifth year of study, medical students rotate through the various surgical disciplines, including general, orthopaedic, trauma, neuro- and paediatric surgery. The general surgery rotation is two months in duration. The clinical rotations are at a tertiary hospital, as well as several affiliated secondarylevel hospitals. No formal surgical mentoring programme currently exists at UCT.

Karolinska Institutet (KI) is the only exclusively medical university in Sweden and accepts approximately 320 medical students per year. The programme is five and a half years in duration and includes 11 semesters of study. The first four semesters focus on the basic sciences in the form of "The healthy human" and "Disease and illness" modules and are likewise taught in lecture- and project-based learning. The course "Clinical medicine - surgery" occupies the seventh semester and comprises the disciplines of surgery, anaesthesiology, orthopaedics, and oncology. The students are trained at various hospitals, including two tertiary and two secondary hospitals. Comparable to UCT, no formal surgical mentoring programme currently exists at KI.

\section{Study population}

Medical student clinical exposure varies between the different surgical disciplines in both South Africa and Sweden. To maintain homogeneity, only the general surgery rotation was evaluated. Additionally, only consultants and fellows in general surgery were recruited in the faculty sample. Registrars were excluded as they themselves are in training.

Medical students from UCT and KI, who completed and passed all the necessary examinations of their respective undergraduate general surgery rotation during the 2017 academic year, were included in this study. Similarly, employed staff in the Department or Divisions of General Surgery during the abovementioned period, both consultants and fellows, were included. During the study period, 492 (202 to UCT and 290 to KI) and 55 (20 to UCT and 35 to $\mathrm{KI})$ questionnaires were administered to eligible students and faculty, respectively.

\section{Study procedure}

As there are limited reliable or validated published questionnaires regarding mentorship or role models in surgery, a study-specific questionnaire was designed. The questionnaire was however based on previously published literature, ${ }^{4,12}$ and adapted to the current study question and population. The questionnaire was designed through SurveyMonkey (SurveyMonkey Inc., San Mateo, CA), a secure, online survey development format. The questionnaire was administered anonymously, and all participants were required to give informed consent prior to accessing the online survey.

The questionnaire (Appendices 1-4) consisted of multiple choice, true or false, and five-point Likert scale questions, obtaining demographic information and exploring perceptions of mentorship and role models. In addition, medical students and faculty were asked to rate the most important qualities of a surgical mentor using a five-point Likert scale. As shown in Table I, the qualities were grouped into the following categories: physician, supervisor, teacher, and personal, and were based on investigations by Ullian et al. ${ }^{13}$ and Cochran et al. ${ }^{14}$

To increase reliability, the same questionnaire was distributed to medical students and faculty except for a

Table I: Characteristics of the clinical teacher and mentor as adapted from Ullian et al. ${ }^{13}$ and Cochran et al. ${ }^{14}$

\begin{tabular}{llll}
\hline Physician & Supervisor & Teacher & Personal \\
\hline Attitude/enthusiasm & Student encouragement & Teaching skills & Supportive \\
Clinical competence & Provides feedback & Commitment to teaching & Caring/considerate \\
Empathy & Supervised adequately & Availability & Friendly \\
Fund of knowledge & Set fair expectations & Inspirational ability & Fun to work with
\end{tabular}




\begin{tabular}{|c|c|c|c|}
\hline Medical students $(n=120)$ & UCT $(n=49)$ & KI $(n=71)$ & $p$-value \\
\hline \multicolumn{4}{|l|}{ Gender - $n(\%)$} \\
\hline Female & $30(61.2)$ & $37(52.1)$ & 0.323 \\
\hline Median age - years (IQR) & $24.5(2)$ & $26.4(3)$ & $0.004 *$ \\
\hline Surgical faculty $(n=41)$ & UCT $(n=13)$ & KI $(n=28)$ & $p$-value \\
\hline \multicolumn{4}{|l|}{ Gender - $n(\%)$} \\
\hline Female & $6(46.2)$ & $5(17.9)$ & 0.057 \\
\hline Median age - years (IQR) & $41.6(7)$ & $48.7(11.75)$ & $0.009^{*}$ \\
\hline \multicolumn{4}{|l|}{ Level of training $-n(\%)$} \\
\hline Consultant & $10(76.9)$ & $26(92.9)$ & 0.304 \\
\hline Fellow & $3(23.1)$ & $2(7.1)$ & \\
\hline \multicolumn{4}{|c|}{ Years in surgical practice $-n(\%)$} \\
\hline $0-2$ & $2(15.4)$ & $0(0.0)$ & \\
\hline Female & $0(0.0)$ & $0(0.0)$ & \\
\hline $3-5$ & $2(15.4)$ & $0(0.0)$ & \\
\hline Female & $1(50.0)$ & $0(0.0)$ & \\
\hline $6-8$ & $2(15.4)$ & $3(10.7)$ & \\
\hline Female & $2(100.0)$ & $1(33.3)$ & \\
\hline $9-11$ & $4(30.7)$ & $6(21.4)$ & \\
\hline Female & $2(50.0)$ & $1(16.7)$ & \\
\hline$\geq 12$ & $3(23.1)$ & $19(67.9)$ & \\
\hline Female & $1(33.3)$ & $3(15.8)$ & \\
\hline
\end{tabular}

$\mathrm{IQR}$ - interquartile range

$* p \leq 0.05$

Table III: Mentors and role models during undergraduate surgical training

\begin{tabular}{|c|c|c|c|c|}
\hline Statement & & $\begin{array}{c}\text { True } \\
n(\%)\end{array}$ & $\begin{array}{l}\text { False } \\
n(\%)\end{array}$ & $p$-value \\
\hline \multirow{12}{*}{$\begin{array}{l}\text { Medical students actually had (student response) and } \\
\text { ought to have (faculty response) a mentor during } \\
\text { undergraduate surgical training }\end{array}$} & UCT students $(n=49)$ & $5(10.2)$ & $44(89.8)$ & \multirow{4}{*}{$<0.001^{*}$} \\
\hline & Female & $3(60.0)$ & $27(61.4)$ & \\
\hline & KI students $(n=71)$ & $36(50.7)$ & $35(49.3)$ & \\
\hline & Female & $15(41.7)$ & $22(62.9)$ & \\
\hline & UCT faculty $(n=13)$ & $8(61.5)$ & $5(38.5)$ & \multirow{4}{*}{0.153} \\
\hline & Female & $5(62.5)$ & $1(20.0)$ & \\
\hline & KI faculty $(n=28)$ & $23(82.1)$ & $5(17.9)$ & \\
\hline & Female & $5(21.7)$ & $0(0.0)$ & \\
\hline & Total students $(n=120)$ & $41(34.2)$ & $79(65.8)$ & \multirow{4}{*}{$<0.001^{*}$} \\
\hline & Female & $18(43.9)$ & $49(62.0)$ & \\
\hline & Total faculty $(n=41)$ & $31(75.6)$ & $10(24.4)$ & \\
\hline & Female & $10(32.2)$ & $1(10.0)$ & \\
\hline \multirow{12}{*}{$\begin{array}{l}\text { Medical students actually identified (student response) } \\
\text { and ought to identify (faculty response) with a role } \\
\text { model during undergraduate surgical training }\end{array}$} & UCT students $(n=49)$ & $29(59.2)$ & $20(40.8)$ & \multirow{4}{*}{0.513} \\
\hline & Female & $16(55.2)$ & $14(70.0)$ & \\
\hline & KI students $(n=71)$ & $41(57.7)$ & $30(42.3)$ & \\
\hline & Female & $23(56.1)$ & $14(46.7)$ & \\
\hline & UCT faculty $(n=13)$ & $11(84.6)$ & $2(15.4)$ & \multirow{4}{*}{0.501} \\
\hline & Female & $6(54.5)$ & $0(0.0)$ & \\
\hline & KI faculty $(n=28)$ & $22(78.6)$ & $6(21.4)$ & \\
\hline & Female & $4(18.2)$ & $1(16.7)$ & \\
\hline & Total students $(n=120)$ & $70(58.3)$ & $50(41.7)$ & \multirow{4}{*}{$0.011^{*}$} \\
\hline & Female & $39(55.7)$ & $28(56.0)$ & \\
\hline & Total faculty $(n=41)$ & $33(80.5)$ & $8(19.5)$ & \\
\hline & Female & $10(30.3)$ & $1(12.5)$ & \\
\hline
\end{tabular}




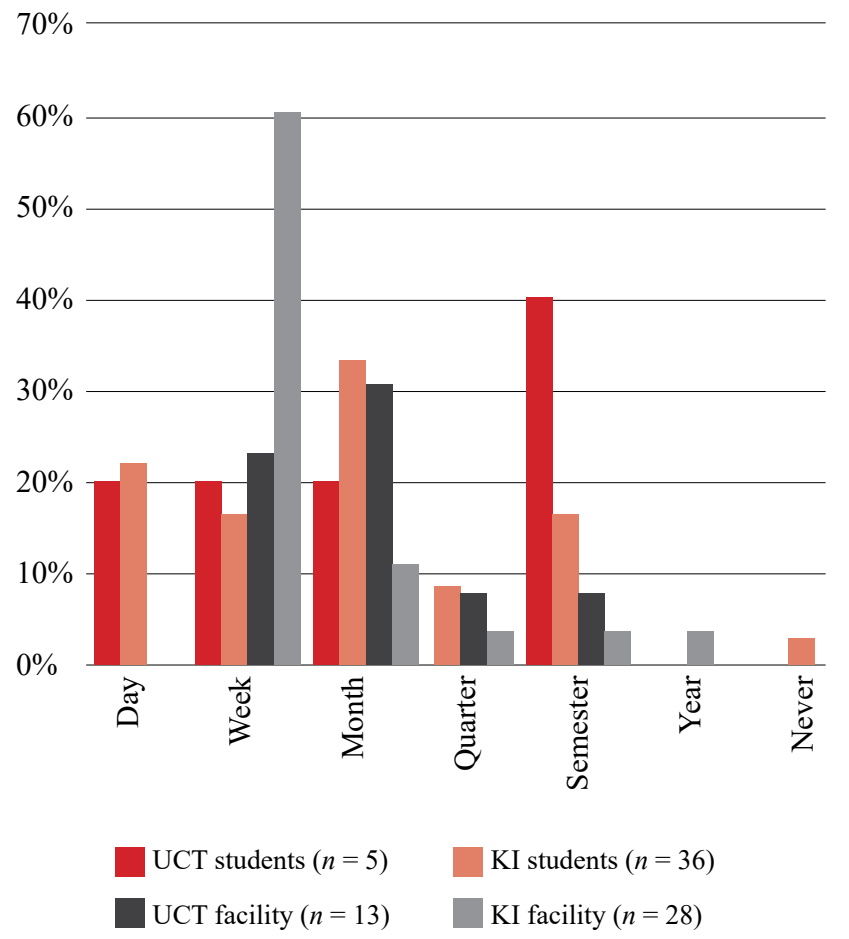

Figure 1: Preferred communication interval between faculty and students who had a mentor

change in wording to correctly address the participants. The questionnaires were distributed in English for participants from UCT, and in Swedish for participants from KI.

\section{Data management and analysis}

Data collected for this study focussed specifically on surgical mentorship and role models and were separated from analysed data previously published. ${ }^{11}$ Data were entered into Microsoft Excel 2016 (Microsoft Corp, Redmond, WA), and descriptive analysis was performed. Data were imported into SPSS 24 (Version 24.0. Armonk, NY: IBM Corp.) for inferential analysis. Student's t-test and the Mann-Whitney $\mathrm{U}$ test were utilised for parametrical and non-parametrical numerical data, respectively. Pearson chi-square or Fisher's exact tests were utilised for categorical data. A $p$-value of $\leq 0.05$ was considered significant.

\section{Results}

A total of 120 (response rate of 24.4\%) students responded, of whom $71(59.2 \%)$ were from KI and 67 (55.8\%) were female. The median age of the student cohort was 25.7 (range 21-40) years. No statistical difference in gender was found between students, however, KI students were significantly older than UCT students $(p=0.004)$. Fortyone (response rate of $74.5 \%$ ) surgical faculty members responded, with $28(68.3 \%)$ based at KI. Among the total faculty cohort, $30(73.2 \%)$ were male, and the median age was 46.4 (range 34-64) years. KI faculty were significantly older than UCT faculty $(p=0.009)$. A summary of student and faculty demographic data is shown in Table II.

As summarised in Table III, 31 (75.6\%) of the total faculty cohort believed that undergraduate students should have a mentor during their surgical training, and 33 (80.5\%) stated that they should identify with a role model. This contrasted with the real-life situation with only $41(34.2 \%)$ students

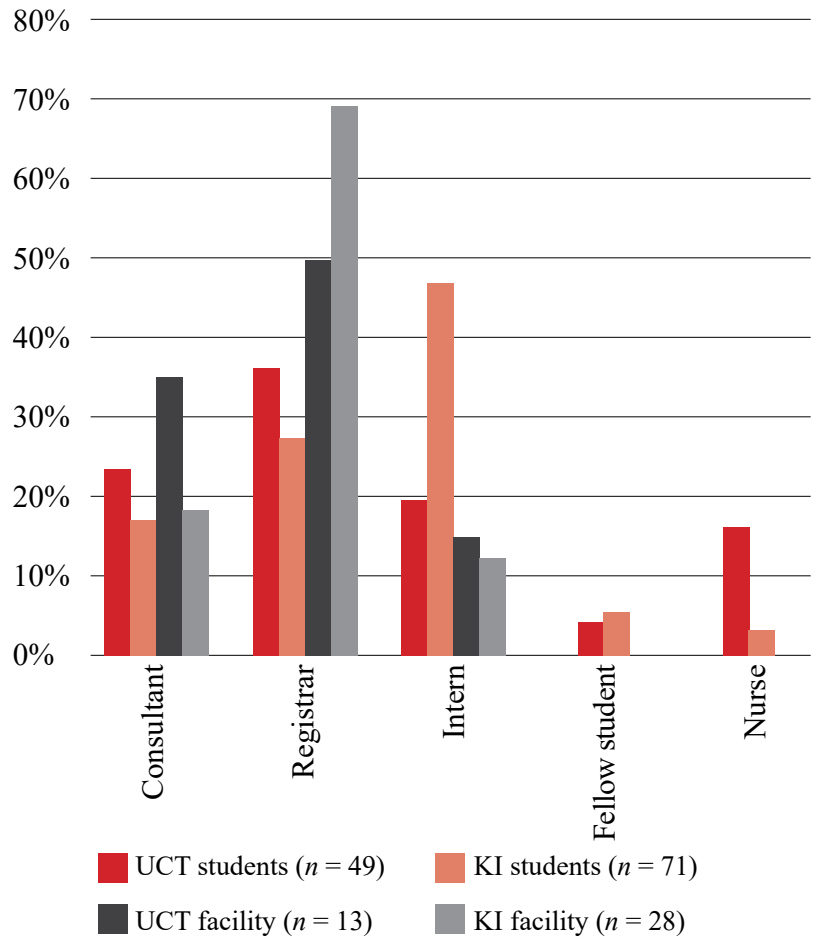

Figure 2: The best role model for medical students

stating they had a mentor during their training, and 70 $(58.3 \%)$ reporting that they had identified with a role model ( $p<0.001$ and $p=0.011$ respectively). No significant differences were found between faculty from UCT and KI in their belief that students ought to have a mentor and identify with a role model during undergraduate surgical training. A significant difference was found between students from the two institutions, with five (10.2\%) UCT students reporting that they had a mentor, compared to $36(50.7 \%) \mathrm{KI}$ students $(p<0.001)$. Of the students at UCT reporting that they had a mentor, three $(60.0 \%)$ were female, compared to $15(41.7 \%)$ females at KI. No significant difference was found between UCT and KI students regarding identifying with a role model during undergraduate surgical training. Furthermore, of the students at UCT and KI who did identify with a role model, $23(56.1 \%)$ and $16(55.2 \%)$ respectively were female. However, of the students at UCT who did not identify with a role model, $14(70.0 \%)$ were female, compared to 14 (46.7\%) females at KI.

As displayed in Figure 1, of the students who had a mentor during their undergraduate surgical training $(n=41)$, approximately one third $(31.7 \%)$ communicated with their mentor monthly. Contrastingly, when asked how often students should communicate with their mentors, almost half of the total faculty cohort $(48.8 \%)$ reported weekly communication. When comparing students who had a mentor between the two institutions, $40.0 \%$ of UCT students communicated with their mentors every semester, whereas $33.3 \%$ of KI students communicated with their mentor monthly. Furthermore, $30.8 \%$ of UCT faculty believed that students ought to communicate with their mentor monthly, whereas the majority of KI faculty $(60.7 \%)$ believed weekly communication should occur.

Figures 2 and 3 depict the best and worst role models as perceived by students and faculty. The 'registrar' was most commonly reported as the best role model for medical 


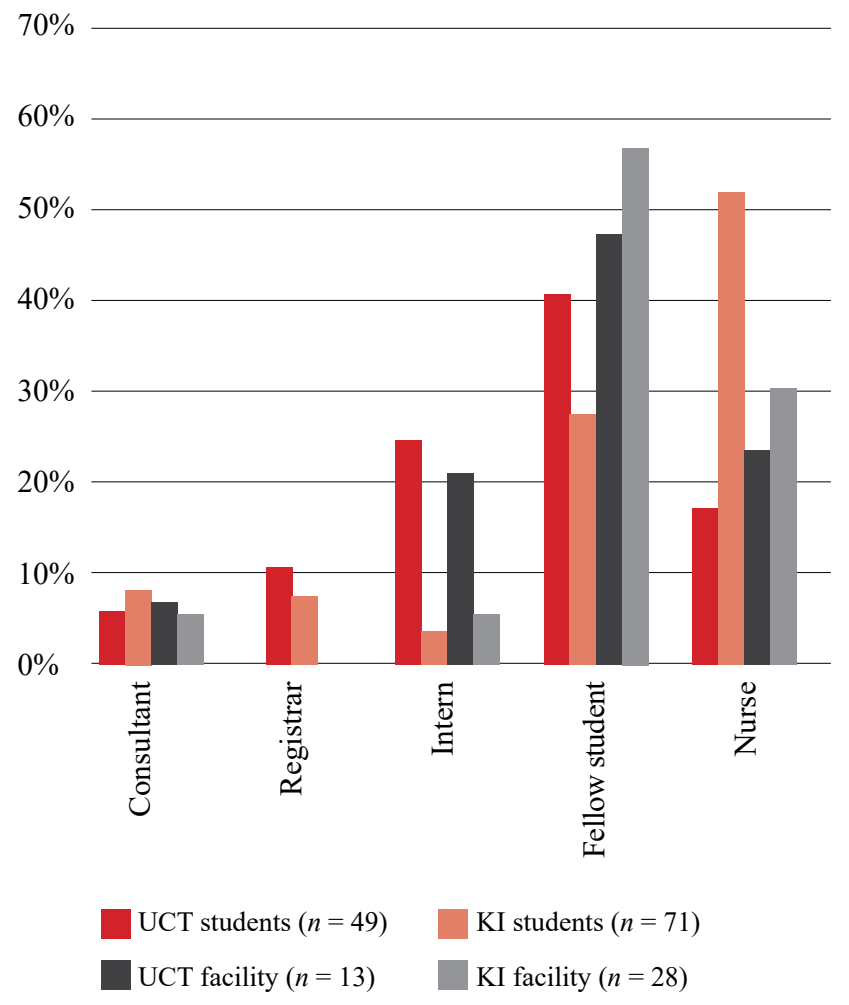

Figure 3: The worst role model for medical students students during their undergraduate surgical training by faculty from both UCT $(50.0 \%)$ and KI $(69.4 \%)$, as well as UCT students (36.6\%). Nearly half of KI students $(46.9 \%)$ stated that the 'intern' was the best role model for medical students. 'Fellow student' was reported as the worst role model for medical students by faculty from both UCT $(47.6 \%)$ and KI (57.1\%), as well as UCT students (41.1\%). Most KI students $(52.2 \%)$ stated that the 'nurse' was the worst role model for medical students.

Responses from students and faculty rating the most important characteristics of a clinical teacher and mentor are displayed in Figure 4. No significant differences were found between student and faculty perceptions in the clusters of 'physician' and 'personal'. In the cluster of 'supervisor', students rated 'student encouragement', 'supervised adequately', and 'set fair expectations' significantly higher when compared to faculty $(p=0.037, p=0.007$ and $p=$ 0.002 respectively). Similarly, 'teacher skills' was rated significantly higher by students when compared to faculty $(p=0.010)$.

\section{Discussion}

In a continuation of analysis of a study exploring medical student and faculty perceptions of undergraduate surgical training, ${ }^{11}$ this article presents medical student and faculty perceptions of mentorship and role models during

Physician qualities: Fund of knowledge

Physician qualities: Empathy

Physician qualities: Clinical competence

Physician qualities: Attitude/enthusiasm

Supervisor qualities: Student encouragement

Supervisor qualities: Provides feedback

Supervisor qualities: Supervised adequately

Supervisor qualities: Set fair expectations

Teacher qualities: Teacher skills

Teacher qualities: Commitment to teaching

Teacher qualities: Availability

Teacher qualities: Inspirational ability

Personal qualities: Supportive, caring, considerate

Personal qualities: Friendly, fun to work with

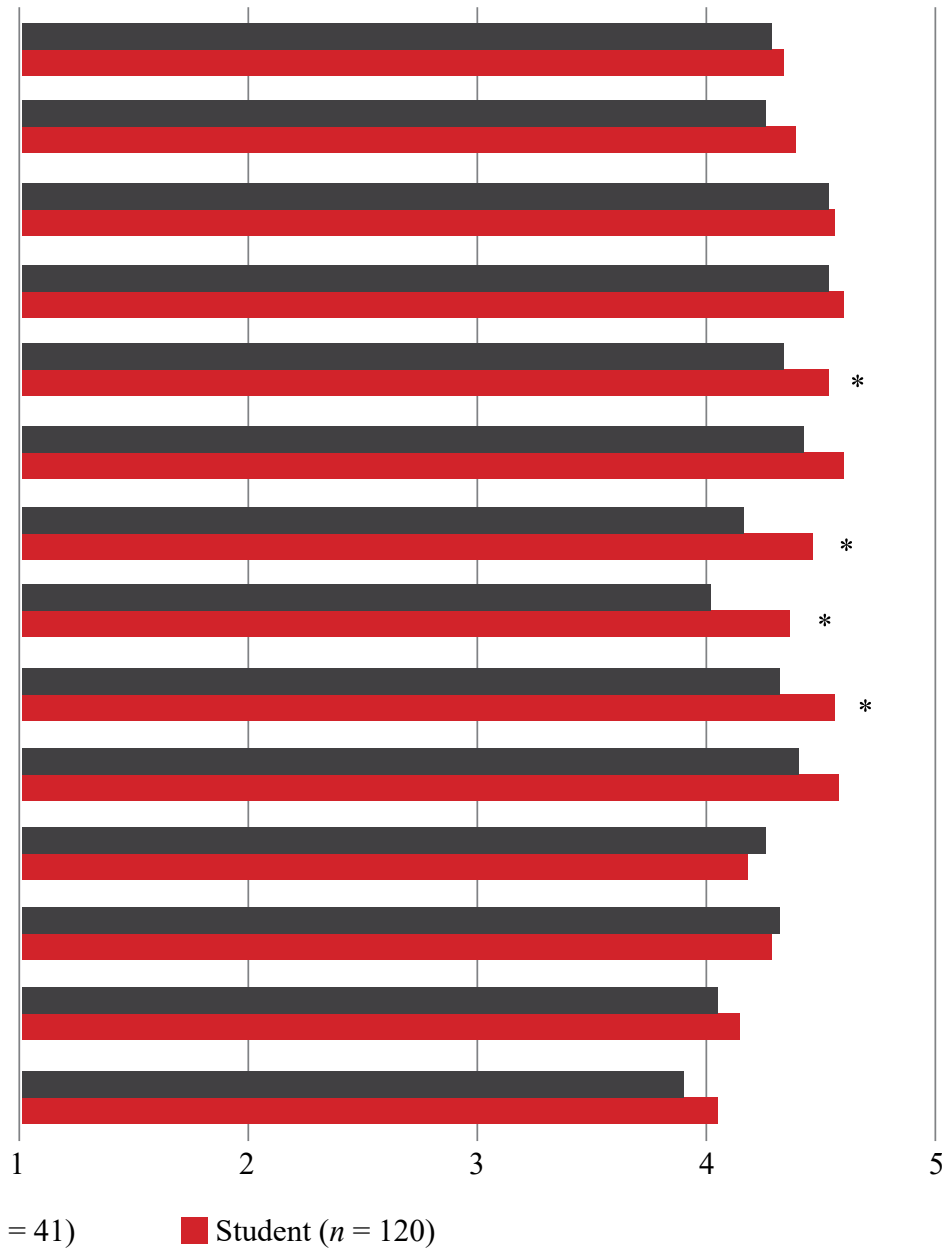

Faculty $(n=41)$

Student $(n=120)$

Figure 4: Student and faculty perceptions of the most important characteristics of a clinical teacher and mentor, as adapted from Ullian et al. ${ }^{13}$ and Cochran et al. ${ }^{14}$

Likert scale items: 1 = Strongly disagree; 2 = Disagree; $3=$ Neither agree nor disagree; $4=$ Agree; $5=$ Strongly agree.

Data are represented as means. ${ }^{*} p \leq 0.05$ by the Mann-Whitney U test. 
undergraduate surgical training and compares results between a South African and Swedish institution.

Students at the two institutions in this study were similar in terms of gender, however, KI students were significantly older. It is possible that this accounted for some of the differences in perceptions between the two student cohorts. When compared to UCT faculty, the faculty from KI were significantly older, reported being in surgical practice longer, and were predominantly male.

Mentorship during undergraduate surgical training has been shown to positively influence medical students, especially through formal mentoring programmes. ${ }^{2,5,7,15-17}$ Numerous studies have reported that mentorship increases interest in surgery, ${ }^{5,16,18-20}$ improves student confidence, ${ }^{15,16}$ and has a positive impact on career planning and academic research. ${ }^{6}$ Role models, both positive and negative, have also been shown to influence medical students in their career choice. ${ }^{21}$ Personality, attitude, clinical competence, clinical skills, and teaching ability have all been shown to be a determinant of a surgeon being deemed a positive or negative role model. ${ }^{2}$ Crucial to improving surgical interest amongst medical students, positive surgical role models significantly influence the decision of medical students to pursue a career in surgery. ${ }^{9,19}$ Conversely, negative surgical role models may deter a medical student from following a surgical career option. ${ }^{4}$

Another postulated reason for reduced interest in surgery, especially in females, is the lack of same-gender role models. ${ }^{9}$ It has been shown that despite similar numbers of males and females graduating from medical school and completing specialist training, females still make up lower percentages in most surgical disciplines. ${ }^{22}$ This is corroborated by the demographic finding in this study where, compared to UCT faculty, an inequality of gender in consultant positions exists within the KI faculty cohort, especially in those who have practiced surgery longer. Despite the higher proportion of female surgical faculty at UCT compared to KI, the current study found little difference in female students identifying with a surgical role model at the two institutions. However, of the students at UCT who did not identify with a surgical role model, $70 \%$ were female. This may corroborate previous reports of females continuously being challenged to find surgical mentors and role models.,23 Gender is an important aspect to developing mentoring relationships as both the mentor and mentee often have similar interests and goals. ${ }^{24}$ Females have also been shown to prefer specialties with a higher proportion of women, which has historically been a criticism of the surgical workplace in general. ${ }^{25}$ Encouragingly, the gender-gap within the surgical field is narrowing, with increasing numbers of females entering surgical posts, as well as more females in senior surgical and academic positions, increasing access to female mentorship. ${ }^{24}$

The current study found that just over a third of the total student cohort had a mentor during their undergraduate surgical training, which was significantly different to the attitude of surgical faculty. Anecdotal evidence exists on the number of medical students who are in surgical mentoring relationships at an undergraduate level. Studies conducted in North America ${ }^{5,8}$ and the United Kingdom ${ }^{20}$ have shown the number of students identifying with surgical role models and having mentors to be as high as $60-80 \%$. In contrast, a study in Ireland ${ }^{4}$ reported that $80 \%$ of senior medical students did not have a surgical mentor. These circumstantial findings are not isolated to the developed world. A study in Nigeria ${ }^{26}$ showed that $84 \%$ of medical students believed they had identified with a surgical role model, whereas a study conducted in Rwanda ${ }^{27}$ found that only $35 \%$ of respondents had a positive mentoring relationship with surgical faculty. Although outside the scope of the current study, several studies have also reported a lack of surgical mentors amongst junior doctors and surgical trainees. ${ }^{4,28,29}$ Interestingly, the current study illustrated significant differences between students from UCT and KI having a surgical mentor. However, the paucity of literature to which this finding can be compared makes it difficult to make specific extrapolations. The evidence does, however, point to a lack of standardised and accessible mentoring relationship formats throughout the surgical curriculum, as well as an insufficient number of positive surgical role models for medical students.

Medical students and surgical faculty in the current study reported contrasting views on the preferred communication intervals between mentors and mentees. Studies have demonstrated similar findings where mentees preferred more frequent communication and on a more personal level, compared to mentor opinion. ${ }^{6,8}$ In addition, many instances of communication in the mentoring relationship have been reported to be informal. ${ }^{2,30}$ Students from both developing and developed countries have a desire for formal mentoring programmes. ${ }^{4,10}$ Mentoring programmes that are structured and formalised have been shown to be highly effective in improving student academic performance, increasing research productivity, growing interest in specialties, as well as providing the student with an increased sense of support and overall well-being during undergraduate training. ${ }^{30}$ Despite these well-established benefits, Healy et al. ${ }^{2}$ argued that unless there is early interest and agreed involvement from both mentor and mentee, little will be gained from compulsory encounters within formal mentoring programmes in terms of personal and professional development.

Surgical registrars, or residents, are ideally suited to be primary teachers, role models, and mentors to medical students due to the extent of their daily interaction, as well as their understanding of the challenges that graduating medical students are soon to face. . $^{1,5,16,31,32}$ This is corroborated by results of the current study where the majority of medical students and surgical faculty from both UCT and KI believed that registrars are the best role models during undergraduate surgical training. However, studies have shown that registrars are often disregarded as mentors, with institutions failing to acknowledge the impact and influence they have on medical students. ${ }^{1,5,33}$ This again highlights the importance of academic institutions encouraging and training registrars to acquire the necessary skills to be able to adequately mentor medical students during their undergraduate education. Furthermore, the important role that registrars play as mentors and role models in undergraduate surgical training, as shown by our data, warrants a more in-depth look into their role and should be a prioritised topic of future research.

Ullian et al. ${ }^{13}$ have described the characteristics of an outstanding clinical teacher and mentor. Their findings illustrated that medical students emphasised 'teacher' qualities. A decade later, Cochran et al., ${ }^{14}$ asking medical students to rate the same characteristics and compare resident and attending surgeon mentors, found that medical students similarly viewed 'teacher' qualities as being most important. 
Interestingly, 'teacher' qualities were deemed important in attending surgeon mentors, whereas 'personal' qualities were regarded most important for resident mentors. This is perhaps not surprising as students may relate to registrars on a more personal level as compared to consultants. In the current study, 'personal' qualities were rated least important by students and faculty from both UCT and KI, which may be attributable to the fact that only consultants and fellows were recruited in the faculty cohort. In a study conducted by Nguyen and Divino, ${ }^{5}$ who used similar methodology and outcome measures to Cochran et al., ${ }^{14}$ students rated residents significantly higher in 12 of the 14 characteristics. However, attending surgeons were rated higher by medical students in the 'physician' qualities. This finding is comparable to results of this study where students and faculty from both UCT and KI perceived 'physician' qualities to be the most important. Once again, this may reflect the surgical faculty sample in our study as students often recognise the wealth of knowledge and clinical competence that experience of a consultant usually brings to their teaching.

In a study conducted by Ravindra and Fitzgerald, ${ }^{20}$ respondents believed that surgical role models should be a good teacher first, followed by being an effective clinician, personable, and finally be a good supervisor. Interestingly, the current study found significant differences between students and faculty in the clusters of 'supervisor' and 'teacher', including qualities such as encouraging students, adequate supervision, setting of fair expectations, and teaching skills. It has been purported that there are elements of supervision within the surgical discipline that are different to mentoring. However, there are also similarities, such as teaching. ${ }^{34}$ It is vital to the success of the student trainee that these roles are fulfilled. It has also been argued that students look for close supervision, encouragement and adequate feedback when performing daily tasks, such as suturing and other surgical procedures. $^{5}$ As consultants often spend less time with students in these activities, it may offer some insight into the reasons for these significant differences. It is important to note that the perceptions of surgical trainees regarding the characteristics of a surgical mentor and role model may change as they progress through their career. Furthermore, despite being ranked for statistical purposes, as well as to isolate areas in which to focus, all the qualities reported are important and should be included in strategies to improve surgeons themselves as role models and mentors.

There are several methodological limitations in the current study. The descriptive, cross-sectional study design inherently compromises validity. The overall response rate of medical students was low compared to that of surgical faculty, which may also limit the validity of results. There is no consensus on what constitutes an adequate response rate, as it has been shown to depend on the way in which data is used. ${ }^{35}$ For example, Nulty ${ }^{36}$ described that even one response that provides information in a teaching evaluation survey has served its purpose in bringing about potential improvements. There is no validated questionnaire available for evaluating the efficacy of mentorship in medical students, which constitutes an inherent limitation. For this research, we adapted the questions, including answering format, from previous literature. ${ }^{4,12}$ We hope that our article will further stimulate interest in and discourse on the topic with future creation of validated and generally applicable questionnaires. It has also been shown that respondents who have been asked to explore their views on mentorship are often subject to two response biases: acquiescence bias, the tendency to give positive responses to 'positive' characteristics regardless of item content, and the halo effect, rating characteristics highly because of an overall positive impression of the mentor. However, these biases have been reported to be uncommon when using Likert scales, as applied in the current study. ${ }^{37}$ Despite conducting this study at two institutions which include several teaching hospitals, only one academic year was evaluated, which may have introduced population bias. As registrars were not included in this study, results may have been confounded as students may have found it problematic in reporting on mentoring and role-modelling solely done by consultants and fellows.

\section{Conclusion}

Perceptions of mentorship and role models during undergraduate surgical training were found to differ between medical students and faculty in this study. These differences may have negative implications for the fostering of surgical interest amongst medical students. Furthermore, the lack of surgical mentors and role models, as well as the underestimation of their value, may add to the perception of surgery as an unattractive career choice.

Surgical faculty should be encouraged to adopt a more active role in mentoring medical students and realise the impact they may have as positive role models. Early intervention may instil a mentoring mentality in medical students, which may potentially assist in mentoring students as future registrars. Academic institutions should also consider introducing formal mentoring programmes where the reported differences in student and faculty attitudes may be addressed. Reconciling and harmonising these differences will be crucial in fostering constructive mentoring relationships.

\section{Acknowledgements}

This study was in fulfilment of the UCT Master of Philosophy (Surgery) degree for Dr Alex J Scott.

\section{Conflict of interest}

The authors report no conflict of interest in this work.

\section{Funding source}

No funding was received for this study.

\section{Ethical approval}

Ethical approval was obtained from the UCT Human Research Ethics Committee (HREC 107/2017 and 014/2019). Following written confirmation by a representative of the KI Ethics Committee, this study did not require ethical approval from KI. Institutional approval was obtained after ethical approval was granted.

\section{ORCID}

AJ Scott (iD https://orcid.org/0000-0003-0647-607X

G Drevin (i) https://orcid.org/0000-0002-8472-9629

M Nilsson (iD https://orcid.org/0000-0002-6215-8132 JEJ Krige (iD https://orcid.org/0000-0002-7057-9156 E Jonas (iD) https://orcid.org/0000-0003-0123-256X 


\section{REFERENCES}

1. Quillin RC, Pritts TA, Davis BR, et al. Surgeons underestimate their influence on medical students entering surgery. J Surg Res. 2012;117:201-6. https://doi.org/10.1016/j.jss.2012.05.064.

2. Healy NA, Cantillon P, Malone C, Kerin MJ. Role models and mentors in surgery. Am J Surg. 2012;204:256-61. https://doi. org/10.1016/j.amjsurg.2011.09.031.

3. Makley AT, Pritts TA. Being a leader - cultivating surgical education. In: Scoggins C, Pollock R, Pawlik T, editors. Surgical mentorship and leadership. Cham: Springer; 2018. p. 215-27. https://doi.org/10.1007/978-3-319-71132-4_21.

4. Healy NA, Glynn RW, Malone C, Cantillon P, Kerin MJ. Surgical mentors and role models - prevalence, importance and associated traits. J Surg Educ. 2012;69(5):633-7. https:// doi.org/10.1016/j.jsurg.2012.04.015.

5. Nguyen SQ, Divino CM. Surgical residents as medical student mentors. Am J Surg. 2007;193:90-3. https://doi.org/10.1016/j. amjsurg.2006.07.011.

6. Janis JE, Barker JC. Medical student mentorship in plastic surgery - the mentor's perspective. Plast Reconstr Surg. 2016;138(5):925-35. https://doi.org/10.1097/PRS.000000000 0002670 .

7. Dimitriadis $\mathrm{K}$, Von der Borch $\mathrm{P}$, Stormann $\mathrm{S}$, et al. Characteristics of mentoring relationships formed by medical students and faculty. Med Educ Online. 2012;17:17242. https://doi.org/10.3402/meo.v17i0.17242.

8. Barker JC, Rendon J, Janis JE. Medical student mentorship in plastic surgery - the mentee's perspective. Plast Reconstr Surg. 2016;137(6):1934-42. https://doi.org/10.1097/PRS.00000000 00002186 .

9. Peel JK, Schlachta CM, Alkhamesi NA. A systematic review of the factors affecting choice of surgery as a career. Can J Surg. 2018;61(1):58-67. https://doi.org/10.1503/cjs.008217.

10. Ssemata AS, Gladding S, John CC, Kiguli S. Developing mentorship in a resource-limited context - a qualitative research study of the experiences and perceptions of the Makerere University student and faculty mentorship programme. BMC Med Educ. 2017;17(1):123. https://doi. org/10.1186/s12909-017-0962-8.

11. Scott AJ, Drevin G, Pavlović L, et al. Medical student and faculty perceptions of undergraduate surgical training in the South African and Swedish tertiary institutions - a crosssectional survey. Adv Med Educ Pract. 2019;10:855-66. https://doi.org/10.2147/AMEP.S216027.

12. De SK, Henke PK, Ailawadi G, Dimick JB, Colletti LM. Attending, house officer, and medical student perceptions about teaching in the third-year medical school general surgery clerkship. J Am Coll Surg. 2004;199:932-42. https:// doi.org/10.1016/j.jamcollsurg.2004.08.025.

13. Ullian JA, Bland CJ, Simpson DE. An alternative approach to defining the role of the clinical teacher. Acad Med. 1994;69(10):832-8. https://doi.org/10.1097/00001888-19941 0000-00013.

14. Cochran A, Paukert JL, Scales EM, Neumayer LA. How medical students define surgical mentors. Am J Surg. 2004;187(6):698-701. https://doi.org/10.1016/j.amjsurg.200 3.12.053.

15. Day KM, Schwartz TM, Rao V, et al. Medical student clerkship performance and career selection after a junior medical student surgical mentorship program. Am J Surg. 2016;211:431-6. https://doi.org/10.1016/j.amjsurg.2015.10.007.

16. Drolet BC, Sangisetty S, Mulvaney PM, Ryder BA, Cioffi WG. A mentorship-based preclinical elective increases exposure, confidence, and interest in surgery. Am J Surg. 2014;207:17986. https://doi.org/10.1016/j.amjsurg.2013.07.031.
17. Kalén S, Ponzer S, Silén C. The core of mentorship: medical students' experiences of one-to-one mentoring in a clinical environment. Adv Health Sci Educ. 2012;17:389-401. https://oi.org/10.1007/s10459-011-9317-0.

18. Marshall DC, Salciccioli JD, Walton SJ, et al. Medical student experience in surgery influences their career choices - a systematic review of the literature. J Surg Educ. 2015;72(3):438-45. https://doi.org/10.1016/j.jsurg.2014.10.0 18.

19. O'Herrin JK, Lewis LF, Rikkers LF, Chen H. Why do students choose careers in surgery? J Surg Res. 2004;119(2):124-9. https://doi.org/10.1016/j.jss.2004.03.009.

20. Ravindra P, Fitzgerald JEF. Defining surgical role models and their influence on career choice. World J Surg. 2011;35:704-9. https://doi.org/10.1007/s00268-011-0983-0.

21. Glynn RW, Kerin MJ. Factors influencing medical students and junior doctors in choosing a career in surgery. Surgery. 2010;8:187-91. https://doi.org/10.1016/j.surge.2009.11.005.

22. Bruce AN, Battista A, Plankey MW, Johnson LB, Marshall MB Perceptions of gender-based discrimination during surgical training and practice. Med Educ Online. 2015;20(1):25923. https://doi.org/10.3402/meo.v20.25923.

23. Feldman MD, Arean PA, Marshall SJ, Lovett M, O'Sullivan P. Does mentoring matter - results from a survey of faculty mentees at a large health sciences university. Med Educ Online. 2010;15:5063. https://doi.org/10.3402/meo.v15i0.5063.

24. Faucett EA, McCrary HC, Milinic T, et al. The role of samesex mentorship and organizational support in encouraging women to pursue surgery. Am J Surg. 2017;214:640-4. https:// doi.org/10.1016/j.amjsurg.2017.07.005.

25. Jagsi R, Griffith KA, DeCastro RA, Ubel P. Sex, role models, and specialty choices among graduates of US medical schools in 2006-2008. J Am Coll Surg. 2014;218(3):345-52. https:// doi.org/10.1016/j.jamcollsurg.2013.11.012.

26. Makama JG, Ameh EA. Does general surgery clerkship make a future career in surgery more appealing to medical students? Afr Health Sci. 2010;10(3):292-6.

27. Manirakiza A, Hrdy M, Ginwalla R, Kamanzi B, Calland JF. Mentorship role in the choice of surgery as a career among medical students in Rwanda. Rwanda Med J. 2016;73(3):1720.

28. Jaffer U, Pennell A, Musonda P. General surgical trainee experiences of mentoring - a UK regional audit. J Surg Educ. 2010;67:19-24. https://doi.org/10.1016/j.jsurg.2009.10.004.

29. Sinclair P, Fitzgerald JEF, Hornby ST, Shalhoub J. Mentorship in surgical training - current status and a needs assessment for future mentoring programs in surgery. World J Surg. 2015;39:303-13. https://doi.org/10.1007/s00268-014-2774-X.

30. Frei E, Stamm M, Buddeberg-Fischer B. Mentoring programs for medical students - a review of the PubMed literature 2000-2008. BMC Med Educ, 2010;10:32. https://doi. org/10.1186/1472-6920-10-32.

31. Musunuru S, Lewis B, Rikkers LF, Chen H. Effective surgical residents strongly influence medical students to pursue surgical careers. J Am Coll Surg. 2007;204:164-7. https://doi. org/10.1016/j.jamcollsurg.2006.08.029.

32. Whittaker LD Jr, Estes NC, Ash J, Meyer LE. The value of resident teaching to improve student perceptions of surgery clerkships and surgical career choices. Am J Surg. 2006;191:320-4. https://doi.org/10.1016/j.amjsurg.2005.10.0 29.

33. Castillo-Angeles M, Watkins AA, Acosta D, et al. Mistreatment and the learning environment for medical students on general surgery clerkship rotations - what do key stakeholders think? Am J Surg. 2017;213(2):307-12. https://doi.org/10.1016/j. amjsurg.2016.10.013. 
34. Rashid P, Narra M, Woo H. Mentoring in surgical training. ANZ J Surg. 2015;85(4):225-9. https://doi.org/10.1111/ ans. 13004 .

35. Fan W, Yan Z. Factors affecting response rates of the web survey - a systematic review. Comp Hum Behav. 2010;26(2):132-9. https://doi.org/10.1016/j.chb.2009.10.015.

36. Nulty DD. The adequacy of response rates to online and paper surveys - what can be done? Assess Eval High Educ.
2008;33(3):301-14. https://doi.org/10.1080/0260293070129 3231.

37. Berk RA, Berg J, Mortimer R, Walton-Moss B, Yeo TP. Measuring the effectiveness of faculty mentoring relationships. Acad Med. 2005;80(1):66-71. https://doi. org/10.1097/00001888-200501000-00017. 


\section{Mentorship during undergraduate surgical training - comparing perceptions of medical students and faculty at two institutions in South Africa and Sweden}

Appendix 1: Student questionnaire - English

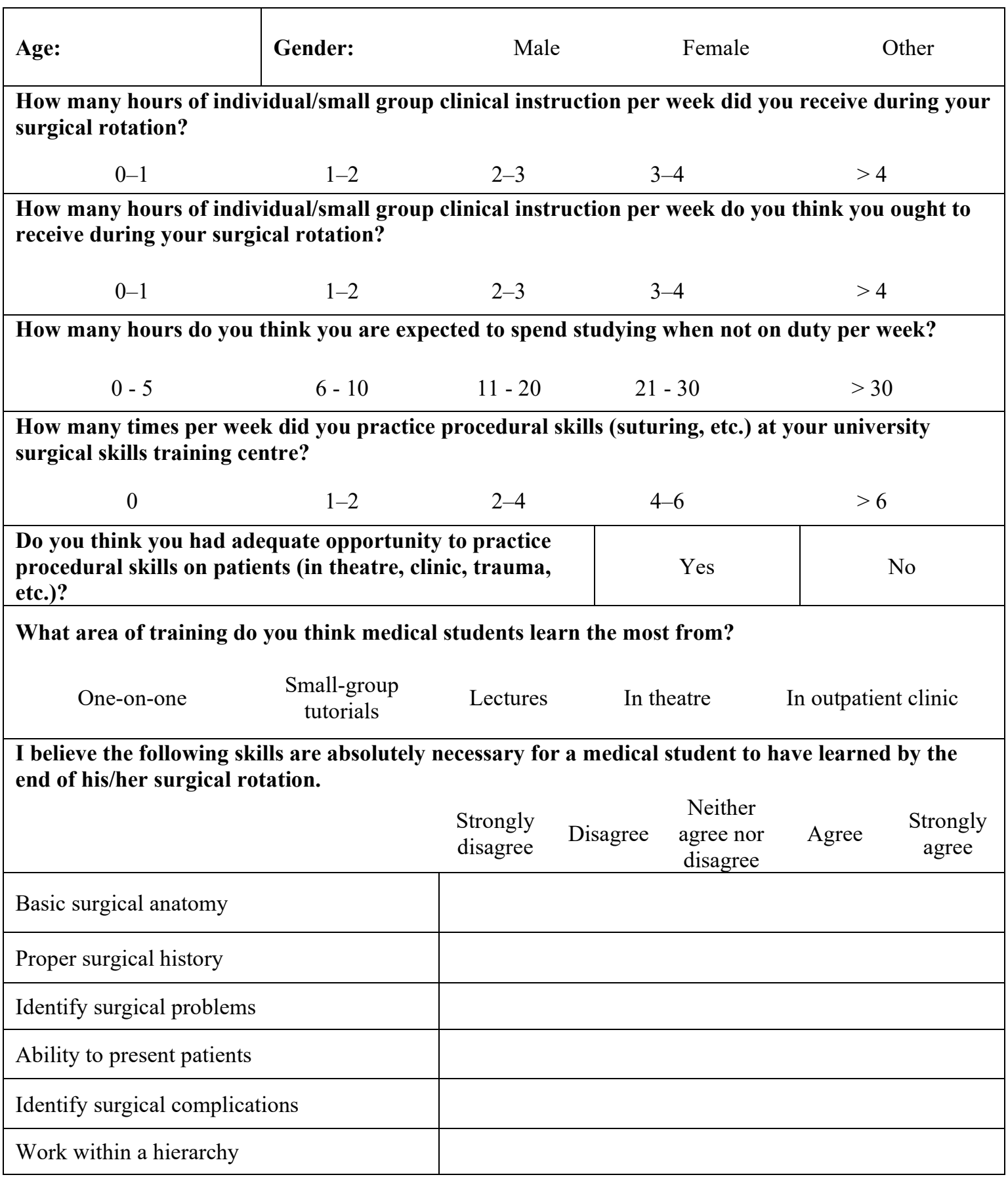




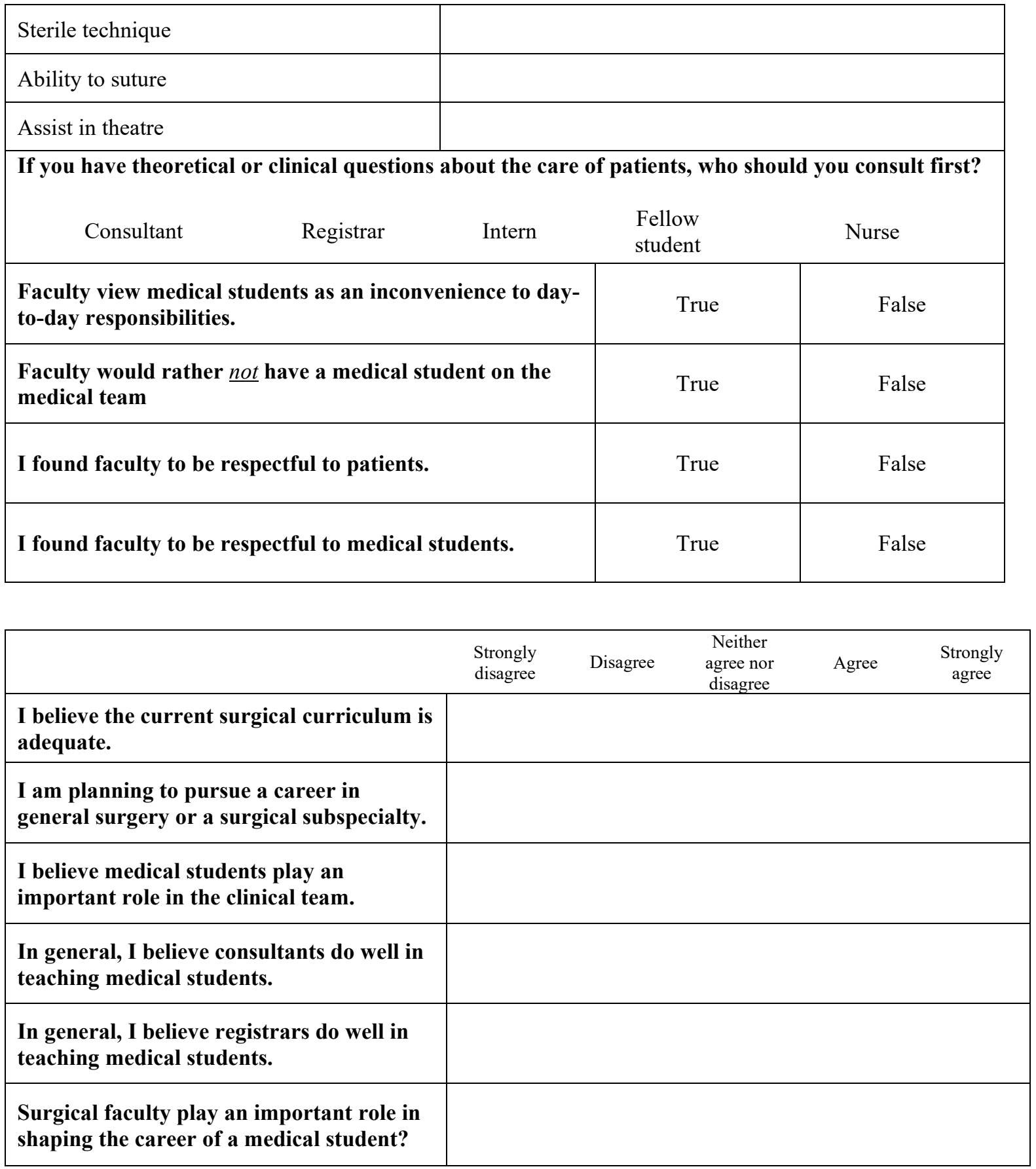




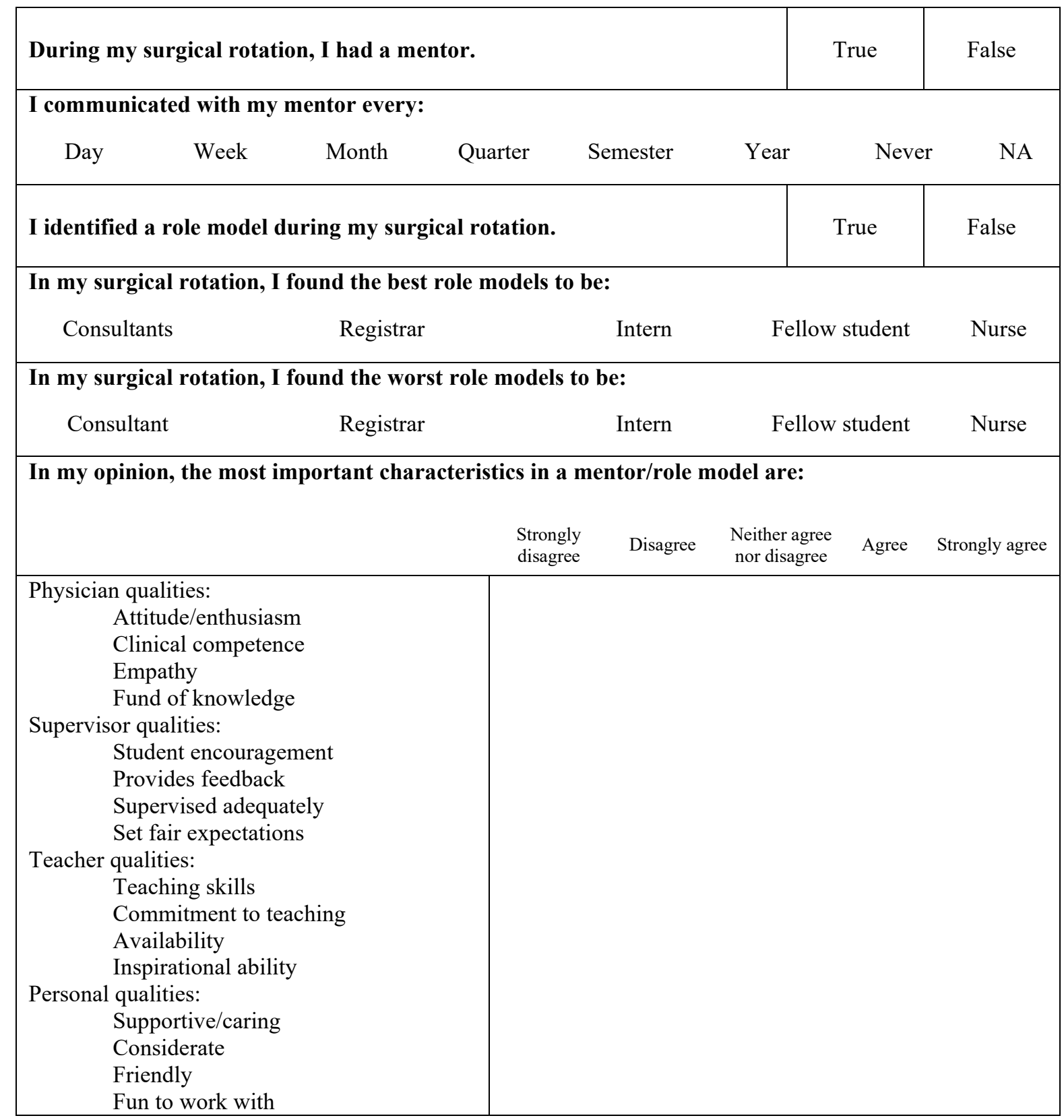


Appendix 2: Student questionnaire - Swedish

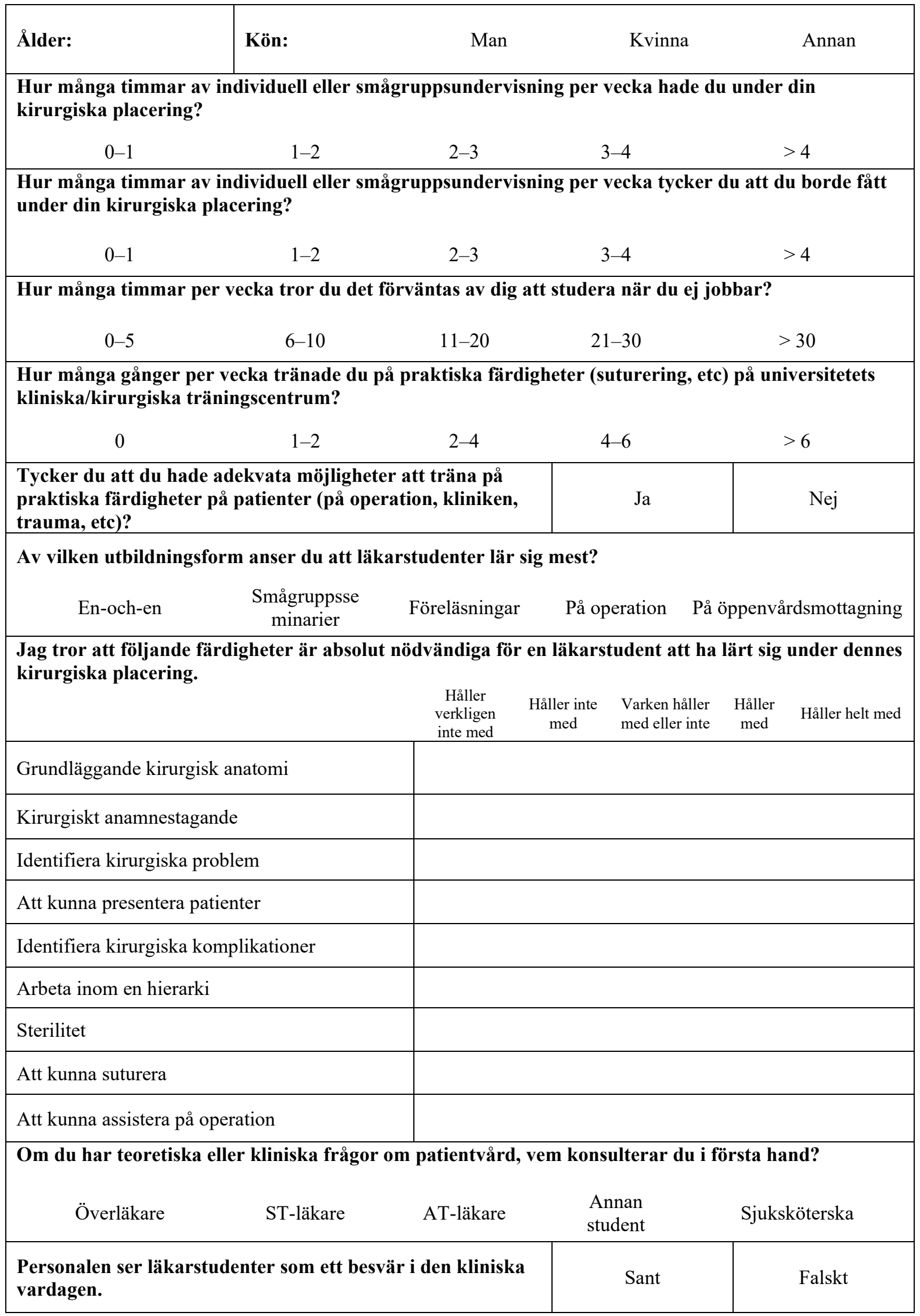




\begin{tabular}{|c|c|c|c|c|c|}
\hline \multicolumn{2}{|c|}{$\begin{array}{l}\text { Personalen skulle hellre } \underline{\text { inte }} \text { ha läkarstudenter i det } \\
\text { medicinska teamet. }\end{array}$} & & Sant & \multicolumn{2}{|c|}{ Falskt } \\
\hline \multicolumn{2}{|l|}{ Jag tycker personalen visar patienter respekt. } & & Sant & \multicolumn{2}{|c|}{ Falskt } \\
\hline \multicolumn{2}{|c|}{ Jag tycker personalen visar läkarstudenter respekt. } & & Sant & \multicolumn{2}{|c|}{ Falskt } \\
\hline & $\begin{array}{l}\text { Håller } \\
\text { verkligen } \\
\text { inte med }\end{array}$ & $\begin{array}{c}\text { Håller inte } \\
\text { med }\end{array}$ & $\begin{array}{l}\text { Varken } \\
\text { håller med } \\
\text { eller inte }\end{array}$ & Håller med & $\begin{array}{l}\text { Håller helt } \\
\text { med }\end{array}$ \\
\hline \multicolumn{6}{|l|}{$\begin{array}{l}\text { Jag tycker de kirurgiska lärandemålen är } \\
\text { adekvata. }\end{array}$} \\
\hline \multicolumn{6}{|l|}{$\begin{array}{l}\text { Jag planerar att göra karriär i } \\
\text { allmänkirurgi eller en kirurgisk } \\
\text { subspecialitet. }\end{array}$} \\
\hline \multicolumn{6}{|l|}{$\begin{array}{l}\text { Jag tycker läkarstudenter är en viktig del } \\
\text { av kliniska teamet. }\end{array}$} \\
\hline \multicolumn{6}{|l|}{$\begin{array}{l}\text { Generellt sett tycker jag överläkare är bra } \\
\text { på att utbilda läkarstudenter. }\end{array}$} \\
\hline \multicolumn{6}{|l|}{$\begin{array}{l}\text { Generellt sett tycker jag ST-läkare är bra } \\
\text { på att utbilda läkarstudenter. }\end{array}$} \\
\hline $\begin{array}{l}\text { Kirurgisk personal spelar en viktig roll i } \\
\text { att påverka en läkarstudents karriär. }\end{array}$ & & & & & \\
\hline
\end{tabular}

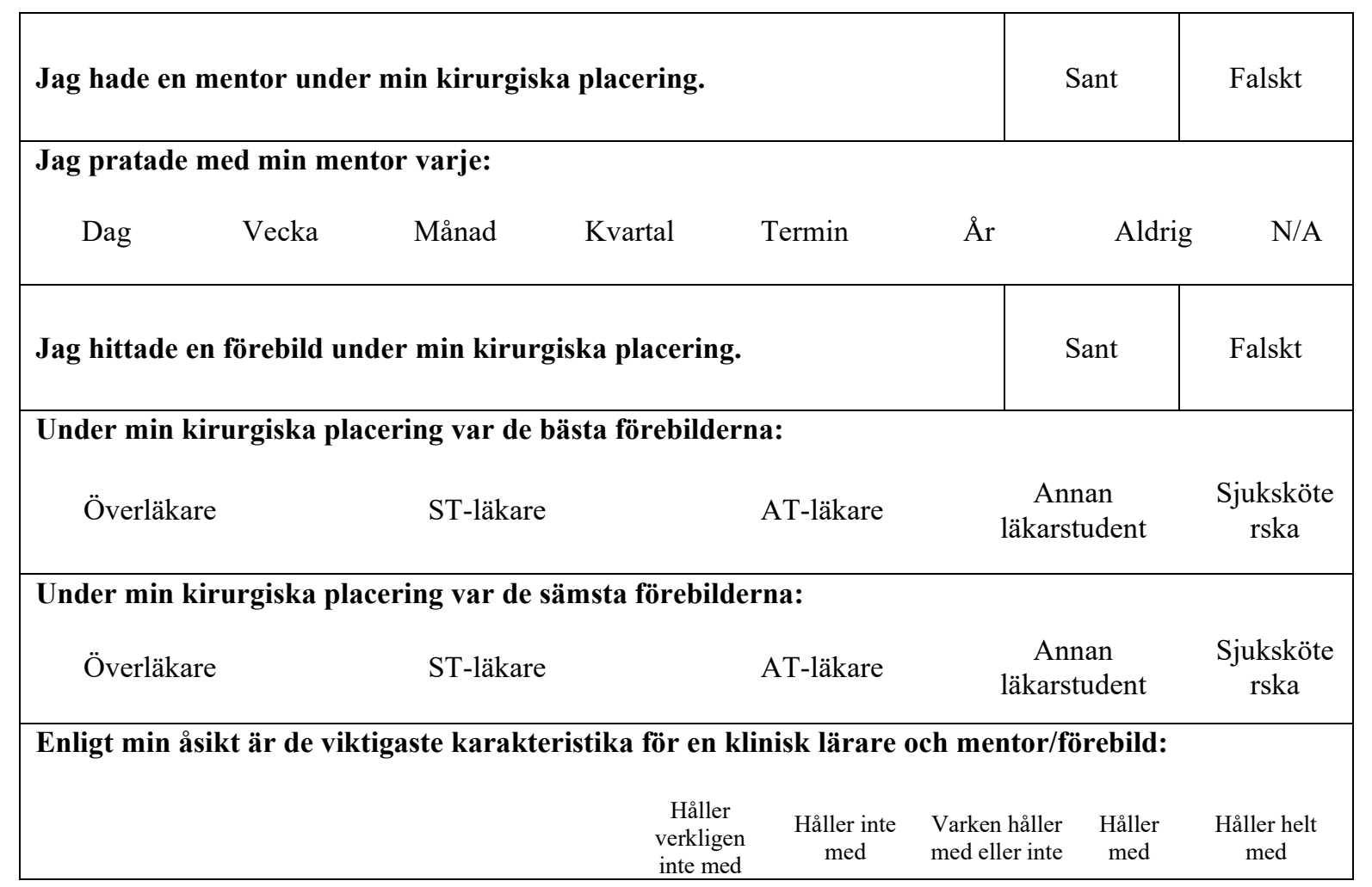


Läkaregenskaper:

Attityd/entusiasm

Klinisk skicklighet

Empati

Kunskap

Handledaregenskaper:

Studentuppmuntrande

Ger feedback

Adekvat handledning

Rättvisa förväntningar

Utbildningsegenskaper:

Utlärandeskicklighet

Vilja att lära ut

Tillgänglighet

Inspirerande förmåga

Personliga egenskaper:

Stöttande, omsorgsfull, omtänksam

Vänlig, rolig att arbeta med 
Appendix 3: Faculty questionnaire - English

\begin{tabular}{|c|c|c|c|c|}
\hline Age: & Gender: & Male & Female & Other \\
\hline Level of training: & \multicolumn{2}{|c|}{ Consultant } & \multicolumn{2}{|c|}{ Fellow } \\
\hline \multicolumn{5}{|c|}{ Years in surgical practice: } \\
\hline $0-2$ & $3-5$ & $6-8$ & $9-11$ & $>12$ \\
\hline
\end{tabular}

How many hours of individual/small group clinical instruction per week do you give medical students during their surgical rotation?
$0-1$
$1-2$
$2-3$
3-4
$>4$

How many hours of individual/small group clinical instruction per week do you think medical students ought to receive during their surgical rotation?
$0-1$
$1-2$
$2-3$
$3-4$
$>4$

How many hours do you think medical students are expected to spend studying when not on duty per week?
$0-5$
$6-10$
$11-20$
$21-30$
$>30$

How many times per week did you think medical students get to practice procedural skills (suturing, etc.)?
0
$1-2$
$2-4$
4-6
$>6$

Do you think medical students have adequate opportunity to practice procedural skills on patients (in theatre, clinic, trauma, etc.)?

What area of training do you think medical students learn the most from?
One-on-one
Small-group tutorials
Lectures
In theatre
In outpatient clinic

I believe the following skills are absolutely necessary for a medical student to have learned by the end of his/her surgical rotation.

\begin{tabular}{|c|c|c|c|c|c|}
\hline & $\begin{array}{l}\text { Strongly } \\
\text { disagree }\end{array}$ & Disagree & $\begin{array}{l}\text { Neither agree } \\
\text { nor disagree }\end{array}$ & Agree & Strongly agree \\
\hline \multicolumn{6}{|c|}{ Basic surgical anatomy } \\
\hline \multicolumn{6}{|c|}{ Proper surgical history } \\
\hline \multicolumn{6}{|c|}{ Identify surgical problems } \\
\hline \multicolumn{6}{|c|}{ Ability to present patients } \\
\hline \multicolumn{6}{|c|}{ Identify surgical complications } \\
\hline \multicolumn{6}{|c|}{ Work within a hierarchy } \\
\hline \multicolumn{6}{|l|}{ Sterile technique } \\
\hline \multicolumn{6}{|l|}{ Ability to suture } \\
\hline Assist in theatre & & & & & \\
\hline
\end{tabular}




\begin{tabular}{|c|c|c|}
\hline \multicolumn{3}{|c|}{$\begin{array}{l}\text { If medical students have theoretical or clinical questions about the care of patients, who should they } \\
\text { consult first? }\end{array}$} \\
\hline Consultant & $\begin{array}{l}\text { Fellow } \\
\text { student }\end{array}$ & Nurse \\
\hline $\begin{array}{l}\text { I find teaching medical students an inconvenience to my day- } \\
\text { to-day responsibilities. }\end{array}$ & True & False \\
\hline $\begin{array}{l}\text { If I had a choice, I would rather } \underline{n o t} \text { have a medical student } \\
\text { on my medical team. }\end{array}$ & True & False \\
\hline
\end{tabular}

\begin{tabular}{|c|c|c|c|c|c|}
\hline & $\begin{array}{l}\text { Strongly } \\
\text { disagree }\end{array}$ & Disagree & $\begin{array}{l}\text { Neither } \\
\text { agree nor } \\
\text { disagree }\end{array}$ & Agree & $\begin{array}{c}\text { Strongly } \\
\text { agree }\end{array}$ \\
\hline \multicolumn{6}{|l|}{$\begin{array}{l}\text { I believe the current undergraduate } \\
\text { surgical curriculum is adequate. }\end{array}$} \\
\hline \multicolumn{6}{|l|}{$\begin{array}{l}\text { I believe medical students play an } \\
\text { important role in the clinical team. }\end{array}$} \\
\hline \multicolumn{6}{|l|}{$\begin{array}{l}\text { In general, I believe consultants and } \\
\text { fellows do well in teaching medical } \\
\text { students. }\end{array}$} \\
\hline \multicolumn{6}{|l|}{$\begin{array}{l}\text { I am very consistent with the methods that } \\
\text { I use to evaluate students. }\end{array}$} \\
\hline \multicolumn{6}{|l|}{$\begin{array}{l}\text { I always give feedback to students } \\
\text { throughout their surgical rotation, even if } \\
\text { unsolicited. }\end{array}$} \\
\hline $\begin{array}{l}\text { I play an important role in shaping the } \\
\text { career of a medical student. }\end{array}$ & & & & & \\
\hline
\end{tabular}

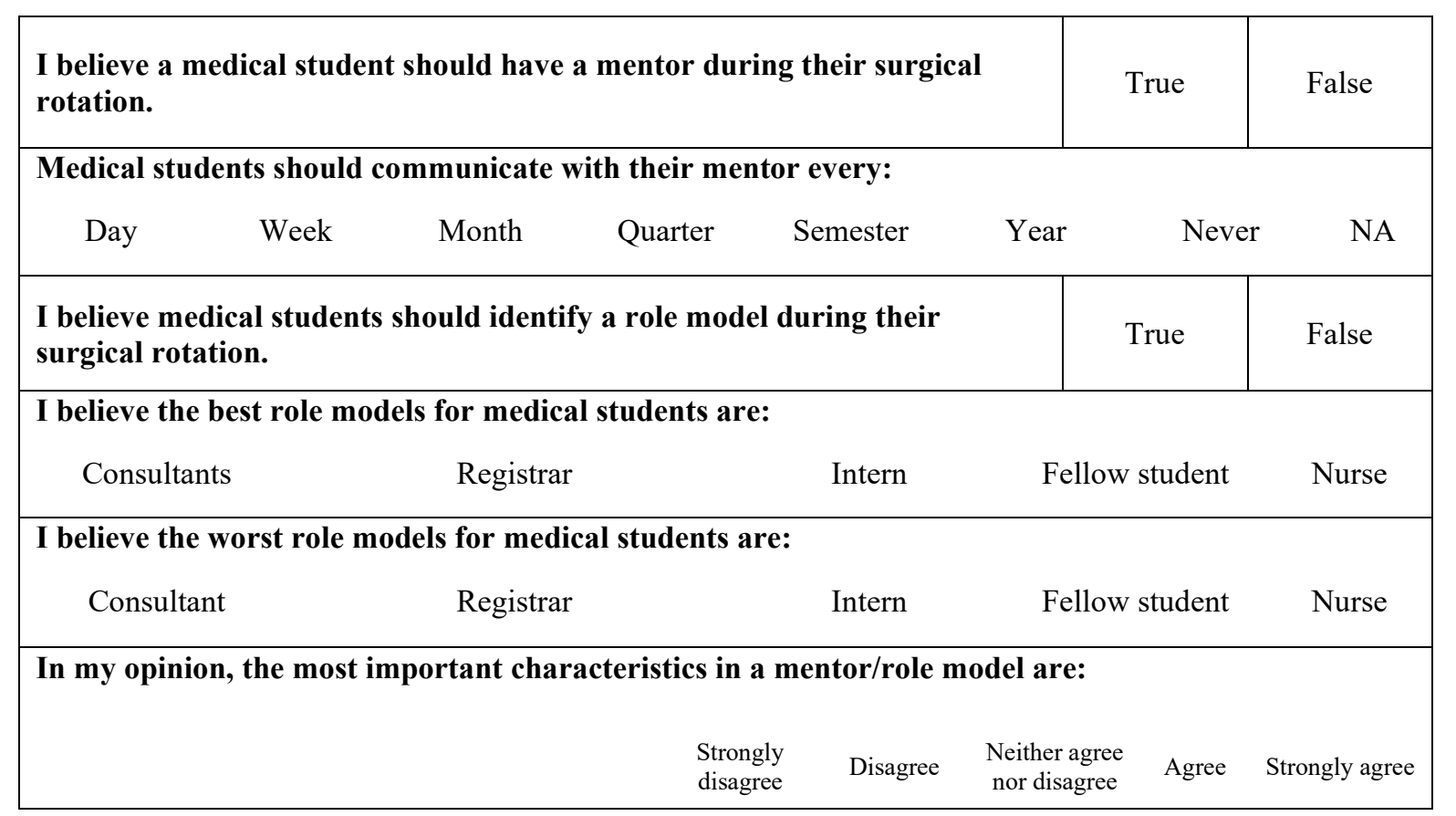




\begin{tabular}{|l|l|}
\hline Physician qualities: & \\
Attitude/enthusiasm & \\
Clinical competence & \\
Empathy & \\
Fund of knowledge & \\
Supervisor qualities: & \\
Student encouragement & \\
Provides feedback & \\
Supervised adequately & \\
Set fair expectations & \\
Teacher qualities: & \\
Teaching skills & \\
Commitment to teaching & \\
Availability & \\
Inspirational ability & \\
Personal qualities: & \\
Supportive/caring & \\
Considerate & \\
Friendly & \\
Fun to work with & \\
\hline
\end{tabular}


Appendix 4: Faculty questionnaire - Swedish

\begin{tabular}{|c|c|c|c|c|}
\hline Ålder: & Kön: & Man & Kvinna & Annan \\
\hline Specialiseringsnivå: & \multicolumn{2}{|c|}{ Överläkare } & \multicolumn{2}{|c|}{ Specialist } \\
\hline \multicolumn{5}{|c|}{ År av kirurgisk tjänstgöring: } \\
\hline $0-2$ & $3-5$ & $6-8$ & $9-11$ & $>12$ \\
\hline
\end{tabular}

Hur många timmar av individuell/gruppbaserad utbildning ger du per vecka till läkarstudenter under deras kirurgiska placering?
$0-1$
$1-2$
$2-3$
3-4
$>4$

Hur många timmar av individuell/gruppbaserad utbildning tycker du läkarstudenter borde erhålla under deras kirurgiska placering?
$0-1$
$1-2$
$2-3$
$3-4$
$>4$

Hur många timmar per vecka tror du läkarstudenter förväntas studera när de ej har klinisk placering placering?
$0-5$
$6-10$
$11-20$
$21-30$
$>30$

Hur många gånger per vecka tror du läkarstudenter făr träna på praktiska kliniska färdigheter (suturering, etc)?
0
$1-2$
2-4
4-6
$>6$

Tycker du läkarstudenter har tillräckligt med möjligheter att träna på praktiska kliniska färdigheter på patienter (på operation, kliniken, trauma, etc)?

Av vilken utbildningsform anser du att läkarstudenter lär sig mest?

En-och-en $\quad \begin{gathered}\text { Smågruppsse } \\ \text { minarier }\end{gathered} \quad$ Föreläsningar På operation $\quad$ På öppenvårdsmottagning

Jag tror att följande färdigheter är absolut nödvändiga för en läkarstudent att ha lärt sig under dennes kirurgiska placering.

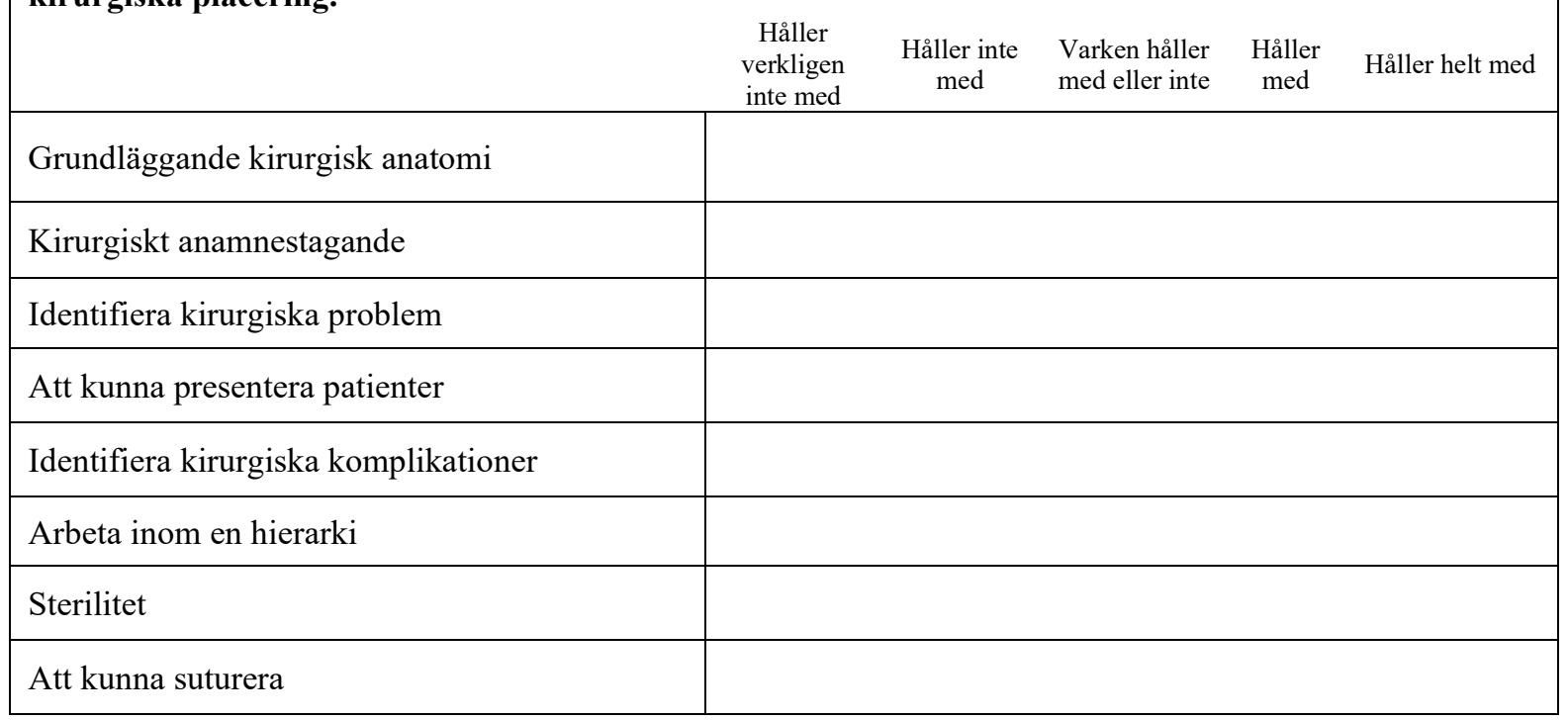


Att kunna assistera på operation

Om läkarstudenter har teoretiska eller kliniska frågor om patientvård, vem borde de konsultera i första hand?
Överläkare
ST-läkare
AT-läkare
Annan student
Sjuksköterska

Jag tycker läkarstudenter är ett besvär i den kliniska vardagen.

Om jag fick välja, skulle jag hellre inte ha läkarstudenter i mitt medicinska team.

\begin{tabular}{|c|c|c|c|c|c|}
\hline & $\begin{array}{l}\text { Håller } \\
\text { verkligen } \\
\text { inte med }\end{array}$ & $\begin{array}{l}\text { Håller inte } \\
\text { med }\end{array}$ & $\begin{array}{l}\text { Varken } \\
\text { håller med } \\
\text { eller inte }\end{array}$ & Håller med & $\begin{array}{l}\text { Håller helt } \\
\text { med }\end{array}$ \\
\hline \multicolumn{6}{|l|}{$\begin{array}{l}\text { Jag tycker de kirurgiska lärandemålen är } \\
\text { adekvata. }\end{array}$} \\
\hline \multicolumn{6}{|l|}{$\begin{array}{l}\text { Jag tycker läkarstudenter är en viktig del } \\
\text { av kliniska teamet. }\end{array}$} \\
\hline \multicolumn{6}{|l|}{$\begin{array}{l}\text { Generellt sett tycker jag överläkare och } \\
\text { ST-läkare är bra på att utbilda } \\
\text { läkarstudenter. }\end{array}$} \\
\hline \multicolumn{6}{|l|}{$\begin{array}{l}\text { Jag är mycket konsistent med metoderna } \\
\text { jag använder för att utvärdera studenter. }\end{array}$} \\
\hline \multicolumn{6}{|l|}{$\begin{array}{l}\text { Jag ger alltid feedback till studenter under } \\
\text { deras kirurgiska placering, även om inte } \\
\text { bedd om det. }\end{array}$} \\
\hline $\begin{array}{l}\text { Jag spelar en viktig roll i att påverka en } \\
\text { läkarstudents karriär. }\end{array}$ & & & & & \\
\hline
\end{tabular}

Jag anser att läkarstudenter ska ha en mentor under deras kirurgiska
placering.
placering.

Läkarstudenter bör prata med sin mentor varje:

Dag Vecka Månad Kvartal Termin År $\quad$ Aldrig N/A

Jag anser att läkarstudenter bör hitta en förebild under deras kirurgiska placering.

Jag tycker den bästa förebilden för läkarstudenter är:
Överläkare
ST-läkare
AT-läkare
Annan
Sjuksköte läkarstudent rska

Jag tycker den värsta förebilden för läkarstudenter är:

Överläkare

ST-läkare
AT-läkare
Sjuksköte läkarstudent 


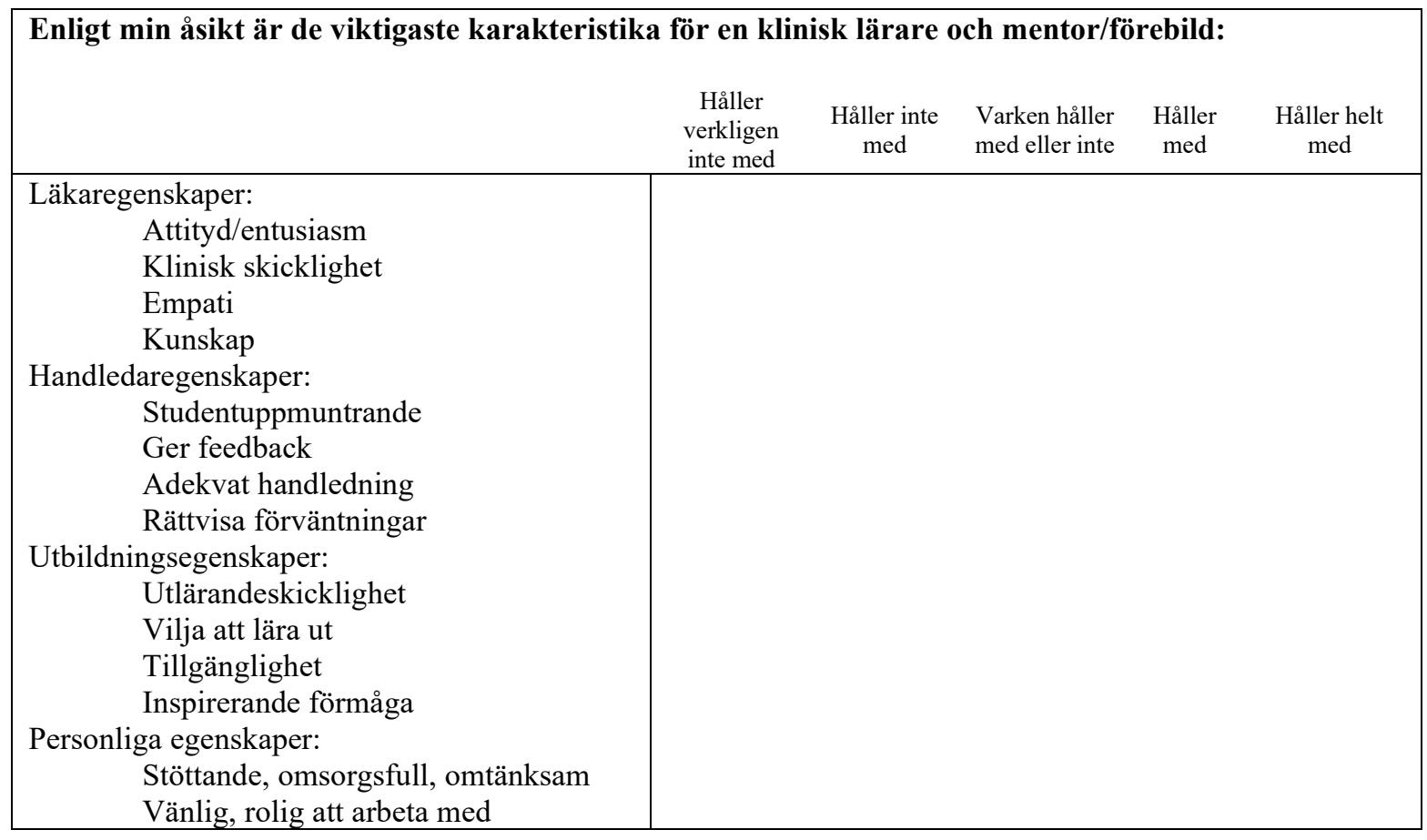

